\title{
Görsel Sanatlarda Malzemeyle Düşünme Ve Sözel Olmayan Bilgi
}

Dr. Öğr. Üyesi Funda Susamoğlu

\section{Özet}

Görsel Sanatlar alanında malzeme olarak tanımlananın sınıları genișlerken, malzeme tercih beraberinde çok katmanlı bir bilgi taşımaktadır. Araştırmanın amacı sözel dilin egemen olduğu hızlı iletişim çă̆ında, malzemenin içeriğinde pratik yoluyla aktarılan sözel olmayan bilginin yapısını irdelemektir. Maddeselliğin merkezde olduğu, malzeme pratiğinin bir bilgi formu olarak ele alındığı "Malzemeyle Düşünme" çalıșmaları, disiplinlerarası yeni bir yaratııı araștırma alanı olarak șekillenmektedir. Pratik yoluyla aktarılan bilgi türünde amaç sözel olmayan ve yapma eyleminin içeriğ̈indeki "tacit" olarak ifade edilen bilgi türünü açı̆̆a çıkarmaktır. Konu üzerine çalışan çağdaş içeriğindeki "tacit" olarak ifade edilen bilgi türünü açı̆̆a çıkarmaktır. Konu üzerine çalışan çă̆daş
bilim felsefecisi Michael Polanyi'nin, nesnel ve kesin bilgi idealine getirdiği eleştirel çalışmaları, yaratıcı düşünme ve görsel sanatlar alanına da katkı yapmaktadır. Görsel sanatlar alanında sözel dilin ve malzemeyle aktarılan örtük bilginin ilișkisi, 60'lar sonrasından günümüze örnekler üzerinden incelenmektedir.

Anahtar Sözcükler: Tacit, Polanyi, Pratik, Malzeme, Sanat

\section{MATERIAL THINKING IN VISUAL ARTS AND NON-DISCOURSIVE KNOWLEDGE}

\section{Abstract}

While the boundaries of what is defined as material in the field of Visual Arts are widening, material preference is accompanied by a multi-layered knowledge. The aim of the research in the age of rapid communication dominated with verbal language is, examining the structure of nonage of rapid communication dominated with verbal language is, examining the structure of non-
discoursive information that is conveyed through practicality in the context of the material. The discoursive information that is conveyed through practicality in the context of the material. The
study of "Material Thinking" is shaped as an interdisciplinary new field of creative research, in which materiality is centred and the material practice is considered as a form of information. The purpose of the knowledge conveyed through practice is to expose the non-discoursive knowledge embedded in the act of making, defined as "tacit" knowing. Michael Polanyi, a contemporary philosopher working on the subject, contributes to the field of creative thinking and visual arts by his critical work discussing the ideal of objective and certain knowledge. The subject is investigated through examples of art work since the 60's till today, looking to the relation of verbal language and the implicit knowledge conveyed by material.

Keywords: Tacit, Polanyi, Practice, Material, Art 
Görsel Sanatlar alanında malzeme olarak tanımlananın sınırları genişlerken, malzeme tercihi beraberinde çok katmanlı bir bilgi taşımaktadır. Araştırmanın amacı sözel dilin egemen olduğu hızlı iletişim çağında, malzemenin içeriğinde pratik yoluyla aktarılan sözel olmayan bilginin yapısını irdelemektir. Malzemenin içeriğindeki bilgi, duyusal olanaklar sunması yanı sıra, kalıcılık ömrü, tarihsel bağları, ilişkilendiği kültür, tekniğiyle insanları eyleme geçirme şekli ve dolaşıma girme biçimiyle katmanlaşmaktadır. Felsefeci Deleuze\&Guattari malzemeyi, akıs halindeki madde, olarak ele alır (Ingold, 2011: 4). Malzeme ile ilişkiye geçildiğinde, bu hareket halindeki maddenin akışının takibinin söz konusu olduğu ifade edilmektedir. Kazı yapan bir arkeolog, malasını toprağın farklı katmanlarını gözleyerek kullanırken 'eylem halindeki sezgi'nin devrede olduğu fikri ele alınmaktadır.

Tim İngold antropoloji ve maddi kültür üzerine çalışan interdisipliner bir araștırmacıdır. Yaratıcıeylemin, en basithaliyleçizimyapmanın, malzemelerle ilişki içinde hareket halinde olmanın yarattığı algıya odaklanmaktadır. Malzeme merkezli bakış açısının günümüze katabileceği yeni olasılıklara ve algıda yaratacağı değişime dikkat çekmektedir. Malzemeler dünyasında hiç bir şey son bulmaz: her şey bir şey olabilir, bir şey olmak her zaman başka bir şey olmak üzere evrilmektedir. Obje merkezli bakış açımızda bugün, bu konu 'geridönüşüm' olarak nitelendirilmektedir. Ama malzeme merkezli bakış açısı ile bu basitçe hayatın kendisidir (Ingold, 2011: 3). Malzemenin sürekli değişim içinde bir yapı olarak yaşam döngüsünün farkındalığını sağladığı ifade edilmektedir.

Maddeselliğin merkezde olduğu, malzeme pratiğinin bir bilgi formu olarak ele alındığı "Malzemeyle Düşünme" çalışmaları, disiplinlerarası yeni bir yaratıı araştırma alanı olarak şekillenmektedir. Sanat, tasarım, mimari, uygulamalı sanatlar ve performans sanatları alanlarını kapsamaktadır. Sözcüklerle transfer edilemeyen ve bir sürecin sonucunda açığa çıkan, pratiğin içeriğindeki bilgi araştırma alanını oluşturmaktadır. Paul Carter, Malzemeyle Düš̈nnme / Material Thinking kitabında bir fikrin vücut bulma sürecini alana özel çözüm üretme ve kolektif üretip düşünme pratiği ile iliskilendirmektedir. Carter, alana özel olanın bedensel ve yerel ile olan bağına da dikkat çekmektedir. Yapan kişi, hem icra eden hem de aynı anda keşif yapan kişi olarak konumlanmaktadır (Carter, 2004: 1-15).

Görsel Sanatlar 70'ler sonrasında biçimci bakış açısından uzaklaşarak eyleme, ilişkisel olana evirildiği günümüzde; maddiolanile bağızayıflamakta ve içerik arayışı bağlam üzerine yoğunlaşmaktadır. Ann Temkin'in Form Düşünmektir/ Thinking is Form başlıkı Beuys incelemesinde 1960'larda heykelin geleneksel malzemeleri olan bronz ve ahşap gibi malzemelerini terk ederek, heykel yapma eylemini performans ve aksiyonları etrafında kurmaya başlaması yanı sıra malzeme kullanımında belirgin bir dilin devamlılık gösterdiğinden bahsetmektedir. Bu yeni estetiğin öne çıkan temel malzemeleri keçe ve yağ ile Beuys, malzemenin sembolik anlam ve çağrışımlarını da kullanmaktadır. Yağ, bir taraftan hayati bir beslenme kaynağıyken, aynı zamanda çürümeye, toplama kamplarında yanan bedenlere, bedensel atığa işaret eder. Keçe sıcak, koruyucu bir izolatör olabilirken, fiber veya sıkıştıııımış saçtan oluşması nedeniyle, benzer bir ikili anlamla bedene referans vermektedir (Temkin ve Rose, 1993:15).

Keçe ve yağ malzeme olarak negatif ve pozitif çağrışımlar taşır, ikisi de iki uçta yapı olarak açık ve kapalı formdan oluşmaktadır. íki malzeme de amorfken, sıkıstırıldıklarında kütlesel bir form kazanmaktadır. Temkin Beuys'un heykel teorisini sıcak ve soğuk zıt kutupların uzlaşması olarak tanımlamaktadır. Termal değişim heykellerinde yağ ile çalışıken etkin bir prensip haline gelmektedir. Yaygın olarak farklı gündelik fonksiyonları olan bu malzemelerin sanat alanında kullanımı, aynı zamanda sanatın lüks bir mal rolüne muhalefet eden çağdaş tartışmanın içinde yer alır. Benzer bir yaklaşımla malzeme kullanımı, $A \mathrm{BDD}^{\prime}$ de süreç sanatında, italya'da Arte Povera akımında kendini göstermektedir (Temkin ve Rose, 1993: 15).

Modern sanatta hazır nesne kullanımı, sanatın beceri ile olan iliskisinin yeniden tanımlanmasını sağlamıştır. El becerisi önceliğini yitirirken, beraberinde sanatçının hazır nesne ile bağlam yaratma becerisi ile sanatta beceri kavramının çerçevesinin yeniden tanımlanması söz konusu olur. Bugün malzeme odaklı uygulamalı sanatlarda da maddi pratiğin kavramsal yönü öne çıkmaktadır. Bir malzeme veya teknikte özelleşme, bu beceri ve bilginin ötesinde, alanlarının yarattığı kültürün ve geleneğin, sosyal bă̆lamlarını malzeme kavrayışarının merkezine alarak üretim pratiği gelişmektedir. Sanatta malzeme olarak tanımlananın, hem fiziksel olarak hem de kavramsal olarak genişlediğini söylemek mümkündür. Bu genişlemeyi gözeterek, pratikle ilgili ve maddi olanın taşıdığı içerik tekrar bir ilgi alanı oluşturmaktadır.

\section{Michael Polanyi ve Tacit ${ }^{1}$ Kavrayış}

Görsel sanatlarda malzemeyle düşünme pratiği, sürekli dönüşüm içinde bir kaynak olarak malzeme farkındalı̆̆ı, çevre ve sürece duyarlı bir bakış açısı geliştirmektedir. Çağdaş sanatta ağırııkı olarak, maddi pratik ve yarattığı

Tacit kelimesi, latince kökenli "sessiz" anlamına gelen "tacitus" kelimesinden türemiștir. Türkçeye örtük, sözsüzz, sessiz, söylenmeden anlaşılan, açıkç̧a söylenmemiş gibi çevirileri karşımıza çıkmaktadır
Metin içinde tüm bu anlamların ortak kavranması adına çeviriden kaçinılmış ve ana metinde geçtiği

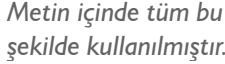


kültür arkeolojik bir alan olarak kavramsallaştırılmaktadır. Dokunarak bakmak veyaparak pratikyoluyla aktarılan bilgi türünde amaç sözel olmayan ve yapma eyleminin içeriğindeki "tacit" olarak ifade edilen bilgi türünü açığa çıkarmaktır. Konu üzerine çalışan çağdaş bilim felsefecisi Michael Polanyi'nin, nesnel ve kesin bilgi idealine getirdiği eleştirel çalışmaları, yaratıcı düşünme ve görsel sanatlar alanına da katkı yapmaktadır.

Polanyi 1958'de yayınladığı Kişisel Bilgi/ Personal Knowledge adlı kitabında, bilimsel bilginin sübjektif yönünü ve aslında her tür bilginin kişisel deneyime dayalı olduğu fikrini irdeler. Bilimin ilerlemesinde tacit kavrayışın, yeni olan bilgiyi tanımlamadaki rolünü ele almıştır. Henüz çözüme ulaşmadan, potansiyel taşıyan verimli bir soruyu veya problemi saptamanın tacit bir kavrayış yoluyla olduğunu dile getirmektedir. Bu nedenle kesin, net veriler üzerine dayanan modern bilimin işleyişine de bir eleştiri geliştirmektedir. Daha sonraki çalışması Tacit Boyut / The Tacit Dimension yayınında bu bilme halinin yapısını irdelemektedir. Insanlık bilgisini yeniden ele alırken, anlatabildiklerimizden daha fazlasını bildiğimiz olgusundan başlamaktayım sözleriyle odak noktasını ifade etmektedir (Polanyi, 1966: 4). Basit bir örnekle milyonlar içinden tanıdığımız bir yüzü, henüz nereden tanıdığımızı bilmeden seçmemiz gibi; düşünme eyleminin her zaman kasıtlı olmak zorunda olmadığını ancak yapılandırılan bir formu olduğunu öne sürmektedir.

Tacit kavrayışın temel yapısı iki evreden oluşmaktadır. Yakınsal evre, detaylar iceren adını koyamadığımız bilgi, bizi uzakta olan evreye taşımaktadır. Öğeleri teker teker tanımlayamasak da, ortak amaçlarını kavramaya adım atarız. Uzakta olanın belirmesi sayesinde yakın olanı tacit olarak biliriz. Uzak evrenin sezilmesi ile yakın evreden başka bir şeye doğru devam edildiği fark edilmektedir (Polanyi, 1966: 9-10).

Polanyi (1966) Tacit Boyut çalışmasında; bir objeyi görme şeklimiz, bedenimizin içinden bazı eforların bilincinde olmamızla ayırt edildiğini ifade etmektedir. Eşlik ettiğimiz objenin pozisyonu, büyüklüğü, biçimi ve hareketinin bedenimizin içinde bir şeyler yarattığını fark ederiz. Diğer bir deyişle içinde bulunduğumuz bu içsel süreçler yoluyla, dışsal şeylerin özelliklerine ulaştı̆̆ımızı, içeriden dışarıyı kavramaktan bahsetmektedir Bedensel deneyimin, dışardaki şeylerin algılanmasına aktarımı, bu nedenle, tüm tacit bilmede bir boyutta bizden uzakta olanın anlamının aktarımının var olduğunu öne sürmektedir (1966: 14).

Örneğin bir alet kullandığımızda, onu uyguladığımız şeyler üzerindeki etkisinin, elimizde yarattığı etkinin anlamına eşlik ederek kavradığımız konusunu ele alır. Bedenimiz normalde dünyada bir obje olarak algılamadığımız tek şeydir, ancak her zaman bedenimiz yoluyla katıldığımız dünya, beden üzerinden deneyimlenmektedir. Bedenimizi kullandığımız şekilde, bir şeyi başka bir şeye katılmak üzere kullandığımızda, bu şeylerin algısının değiştiğini ifade etmektedir. Bu anlamda tacit kavrayışın yakınsal aşamasında bir șeyin işlevini yerine getirdiğimizde, onu bedenimize katarız, ya da bedenimizi onu kapsamak üzere genişletiriz, böylece içinde ikamet etmiş olduğumuzu ifade etmektedir (Polanyi, 1966: 16).

Bugün sanatın eylem, katılım ve ilişkisellik üzerine konsantrasyonu, performans ve yerleştirmeler formunda izleyicinin içinde dolaşımına izin veren, kendi bedensel varlıkları üzerinden kavradıkları bir kurguyu tecrübe etmeleri ile yeni olanaklar sunmaktadır. Sanat izleyicisinin aktif katılımıyla şekillenen, eylem ve tecrübeye dayalı iletişim formu yanı sıra, sadece izleyicinin bakışını talep eden sanat formu da tacit kavrayış ile ilişkilenmektedir. Henüz söze dökülmeden, kişisel deneyim ile kavranan örtük bilgi, sanatın iletişime geçme biçimi ve yapısı üzerine aydınlatıcı bir alan açmaktadır.

\section{Bir Resim Nedir?}

Polanyi'nin 1970 yılında yayınladığı "Bir Resim Nedir / What is a Painting?" makalesinde resim üzerinden sorduğu soru, görsel sanatın iletişim formuna ve görsel algının yapısına odaklanmaktadır. Tacit kavrayışın iki evreli formu, ilk evre odaksal farkındalık, ikincil evre alt algının devrede olduğu, iki ayrı katmandan oluşmaktadır. Gestalt'a paralel bir görüşle bütünden bağımsız parçalara baktığımızda bütünün dağıldığından, resmin yüzey üzerindeki boya tabakalarına dönüştüğünden bahsetmektedir. Ancak algının, resmin üzerine yapıldığı tuvalin varlığını, yani çerçevesinin ikincil farkındalıkla algılanması ile resmin kendine özgü kurgusunu kabul ederek onun içinde hareket ettiğini örneklemektedir.

Konuyu Roma St.Ignazio kilise tavan resmi örneğini ile ele alır, mimarinin parçası olan taşıyıcı kolanlar resmin içinde devam ettirilmiş ve gök yüzüne açılma illüzyonundan oluşmaktadır. Ancak sadece mekanın merkezinde konumlandığınızda resim perspektif olarak doğru algılanmakta ve illüzyon gerçekleşmektedir. Polanyi, bakış açımızı değiş̧irdiğimizde oluşan perspektif deformasyonların, resmin üzerine yapıldığı yüzeyi alt algının kavrayamamasından kaynaklandığını savunmaktadır. 


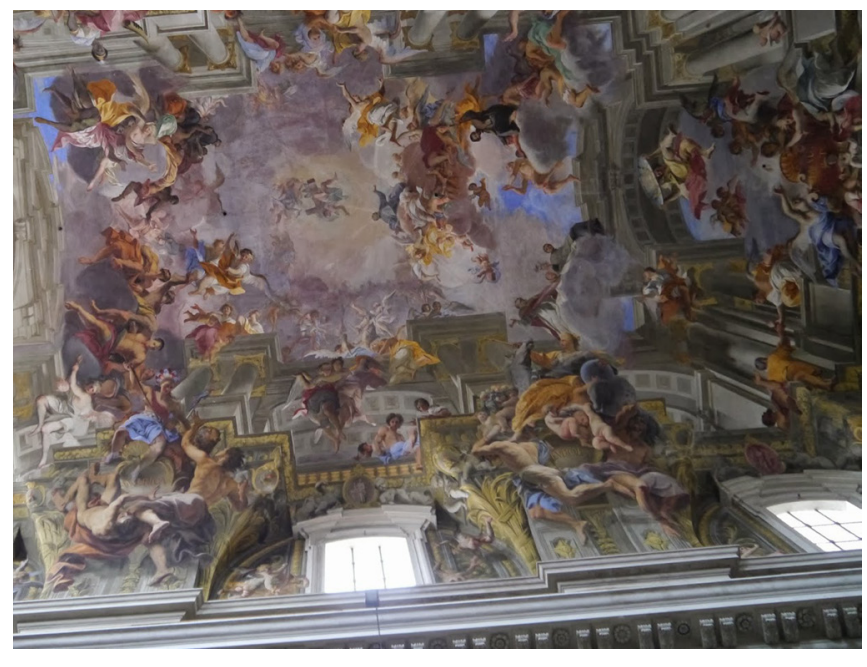

Görsel I. Roma St. Ignazio Kilisesi, Jesuit Andrea Pozzo, I7.yy

Altalgı, bir beceri yapısına sahiptir. Resmin üzerine yapıldığı yüzeyi, tuvalı veya çerçeveyi alt algı ile kavradığımızda bu perspektif deformasyonun gerçekleşmediğini ve resmi kendi içinde değerlendirebildiğini ifade etmektedir. Polanyi'ye göre bu sonuç, algının deneyimin aktif şekillendirilmesi, bilginin takibi izlenmesi ile icra edildiğini örneklemektedir (Polanyi, 1970: 226-227)

Üstünde boya tabakaları bulunan tuvalin, birbirini tamamlayan parçalardan oluşan bir bütün olmasından ziyade, karşıt özelliklerin birleşiminden oluşmaktadır. Düz bir yüzeyde derinlik algısının (flat-depth), kendi içinde inşa ettiği yeni gerçekliğe vurgu yapmaktadır. Deneyimle oluşan bu somut durum, olgusal bir iletişimi değil, hiçbir şeyin doğru ya da yanlış olmadığı yeni bir kavrayışa işaret etmektedir. Doğa ötesi (transnatural) kavramını kullanırken, sanatın doğanın düzeninden farklı yeni bir yapı sunduğunu ifade etmektedir. 19 yy. Modern soyut sanatında, taklit ve temsil etme vurgusunun geri çekilerek, düz yüzey üzerine konsantrasyonun artması ile resmin kendi içinde yarattığı yeni düzene vurgu temel bir mesele olmuştur.

Polanyi (1970) aynı makalede, şiir ve drama alanlarında da benzer bir çelişik yapının mevcut olduğunu ifade etmektedir. Algıyı gündelik gerçeklikten izole etmek için yaratılan 'çerçeve' etkisi, sahne ile sağlanmaktadır. Malzemesi dil olan bir sanat formunun, şiir çerçevesi içinde, uyak, hatalı gramer kullanımı, tekrar yoluyla anlamın dağılıması ve kelimenin sese dönüşmesi gibi düz yazının ötesinde, gündelik mantığın dışında yeni bir içerik ve anlam doğurduğunu vurgulamaktadır (1970: 230-232).

\section{Ölü Bir Tavşana Resmi Nasıl Anlatırsın?}

Bu bölümde 60'lar sonrasında sanatın anlatım formunda yaşanan değişim, sözel dilin ve malzemeyle aktarılan örtük bilginin iliskisi örnekler üzerinden incelenecektir. 60'larda sanatta avangard hareketler, modern sanatın inşaa ettiği sınırları yeniden tanımlamak üzere harekete geçmiştir. Joseph Beuys'un 1965'de gerçekleştirdiği "Ölü bir tavşana resmi nasıı anlatırsın" performansı, sanatın doğrudan eylem ve onun deneyimine dönüştüğü, sanatçının 3 saat boyunca galeride kucağındaki ölü tavşana fısıldayarak dolaşmasıyla gerçekleşmiştir. Şaman ritüellerinden beslenen sanatçının yüzü bal ve altın ile kaplı, ayağında keçe bir tabanlık bağlıdır. Sanatçının görsel dilini oluşturan sıkça kullanıdığı bu ham malzemeler onun için doğanın verimli gücünü temsil etmektedir. Bugünün rasyonalist dünyasında sanatın başka bir düzende iletişim gücüne vurgu yapmaktadır.

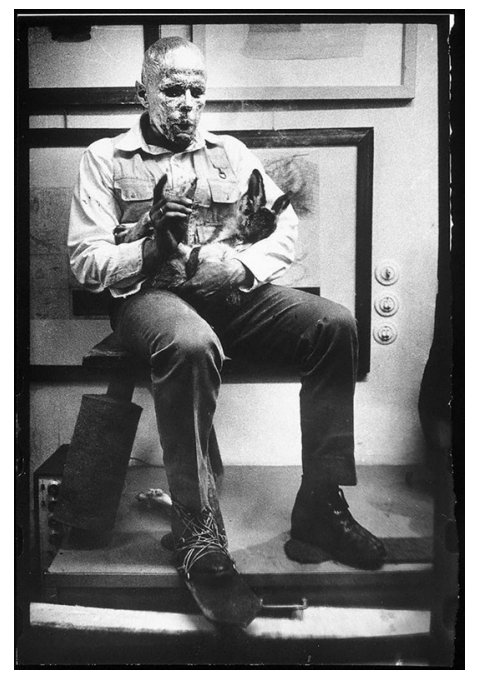

Görsel 2. Joseph Beuys, Ölü bir tavşana resmi nasıl anlatırsın, 1965

Beuys'un önerdiği "toplumsal heykel" kavramı, sanatın toplumu dönüştürme gücüne, bizzat bir parçası olarak eyleme geçmek ve hayata karışmak üzerine kuruludur. Bireysel veya katılımcılarla birlikte gerçekleştirdiği performanslarında, izleyicinin aktif bir rol kazanmaktadır. Sanatın sürece dayalı, performans ve eylem ile güçlenen bağı tacit kavrayışın yaparak içinde ikame ederek kavrama boyutuyla ilişkilenmektedir.

Aynı dönemde Kavramsal Sanat sözel dil ve görsel sanatlar arasında ortak bir alan açmıştır, metin sanatın doğrudan bir aracı ve kavramsal öznesi ha- 
line gelmiş̧ir. Joseph Kosuth'un ikonik çalışması "Bir ve Üç Sandalye", ahşap bir sandalye, sandalyenin fotoğrafı ve sandalye sözcüğğnün sözlükten alınmış tanımının yanyana sunumundan oluşur. Kosuth, görsel algıdan dile, dilden kavrama uzanan zihinsel süreçlerin ardındaki dinamikleri irdeleyerek izleyiciyi felsefi bir sürece ortak etmiştir.

Yapısalcıların ve ardından Post-yapısalcıların dil merkezli eleştirel bakış açısı, bugün de çağdaş sanatın sözel dil ile kurduğu güçlü bağ göz ardı edilemez. Ayşe Erkmen'in Berlin'in Türk mahallesinde gerçekleştirdiği "Evde" çalışması, bir binanın dış cephesine yerleştirilen -mişli geçmiş zaman eklerinden oluşmaktadır. Anadili Almanca olan ikinci nesil Türklerin bakış açısıyla, kişinin bizzat tecrübe etmediği bir zaman kipine işaret etmektedir. Masal anlatımında kullanılan bu form kamusal alanda karşılaştı̆̆ımızda, bizi dilin gündelik kullanım mantığından başka bir hisse sıçramamızı sağlamaktadır. Sözcüklerin eklere bölünmesi sayesinde sağlanan bu kırılma, Polanyi'nin şiir alanında dilin kuralsız kullanımı ile sağlanan yeni anlam örneği ile paralellik göstermektedir.

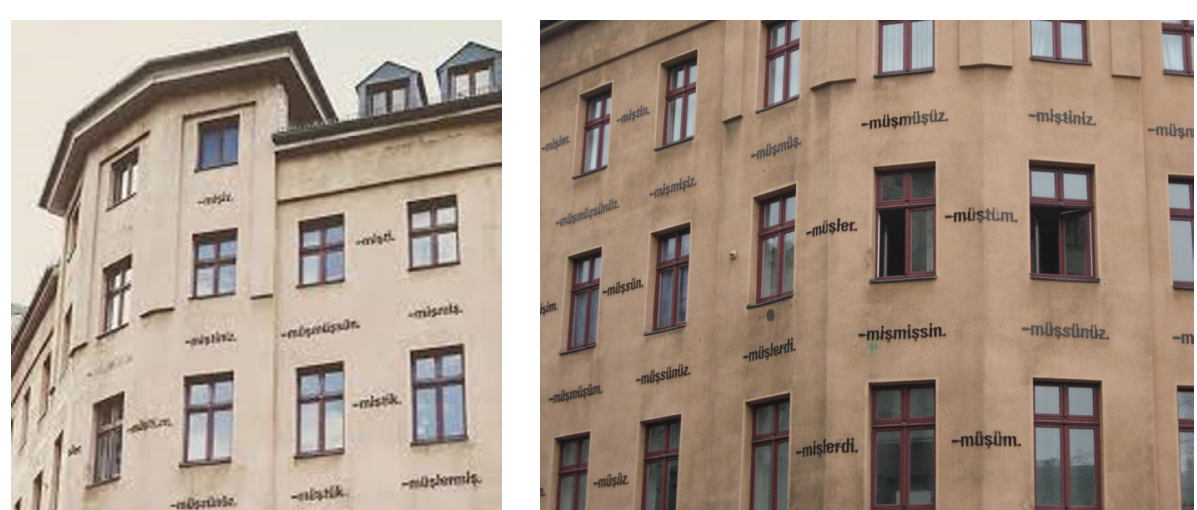

Görsel 3-4. Ayşe Erkmen, Evde, 1994, Berlin.

Sanatın eylem ve mekân ile kurduğu ilişkinin katmanlaşması, alışılmış mekânlarından dışarıya açıımını doğurmuştur. Tuvalin yerini yeryüzünün aldığı minimalist sıçrama, Arazi sanatı örneklerinde, obje ve mülkiyet fikrine muhalefet etmekte ve doğaya yapılan müdahalelerle şekillenmektedir. İskoçya'ı ı sanatçı Andy Goldsworth'ün orman arazilerinde, dal parçaları, taş, buz ve yaprakları kullanarak oluşturduğu çalışmaları, çözülmeye bırakılan geçici yapılardır. Malzemeyle düşünmenin alana özel çözüm üretme pratiği ve doğanın içinde doğal malzemelerle gerçekleştirilen geçici kurgular, sürece ve karşılaşmalara açık bir deneyime vurgu yapmaktadır.
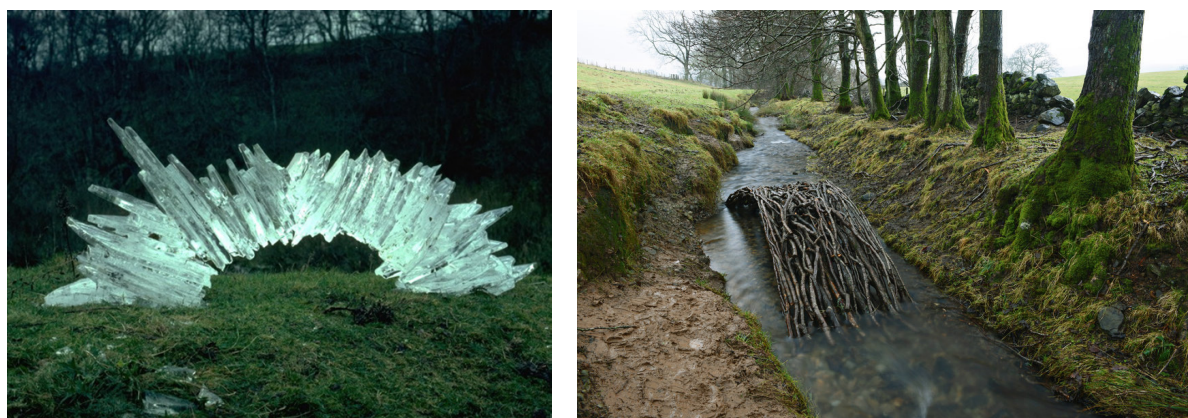

Görsel 5. Andy Goldsworth, 1982 (Solda)

Görsel 6. Andy Goldsworth, 2014 (Să̆da)

Britanyalı sanatçı Phllida Barlow'un tanımsız istilacı yapıları da, binaların içinden dışarıya beklenmedik şekilde önümüze çıkmaktadır. Karton bant, tahta, kumaş parçaları gibi ucuz ve tanıdık malzemelerle inşa ettiği sütrüktürleri için; "Riskli şeyleri, kendini ancak bir arada dengede tutabilen heykel hissini severim. Bir şeylerin düşmek üzere olması hissi ya da düşmüş olması ilgimi çeker. İşin neyle ilgili olduğunu pek bilmeden başlarım, ancak onu yaparken keşfederim" ifadesini kullanır².
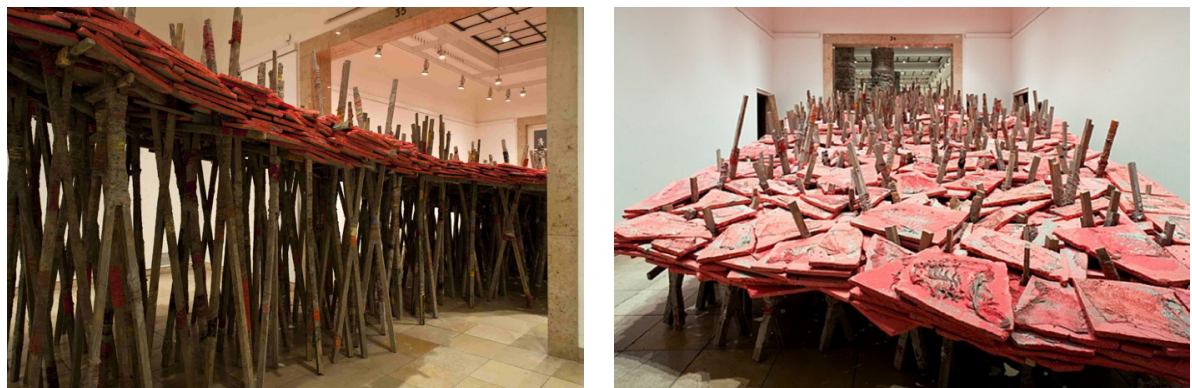

Görsel 7-8. Phllida Barlow, Scultural Acts, 2012, Münih

Barlow, kafasında belirgin bir imge olmadan, inşa etme eyleminin izlendiği, yaparken keşfettiği bir performans olarak değerlendirir çalışmalarını. Günümüzde her alanda gerekçelendirme konusunda büyük bir talep olduğunu, gerekli olmayan, talep edilmeyen, bir mantığı olmayan bir şey yapmanın özgürleştirici olduğunu dile getirir ${ }^{3}$.

Internet: Irish Examiner. (2016, Mart). Web. https://wwwirishexaminercom/breakingnews/entertainment/sculptor-phyllida-barlow-to-represent-britain-at-prestigious-venice-biennale-723734.html 13 Subat $2018^{\prime}$ '

${ }_{3}$ Internet: Carnegine International. (2013). Web: http://cil3.cmoa.org/artists/phyllida-barlow 13 Subat 2018'de alınmıstsı. 

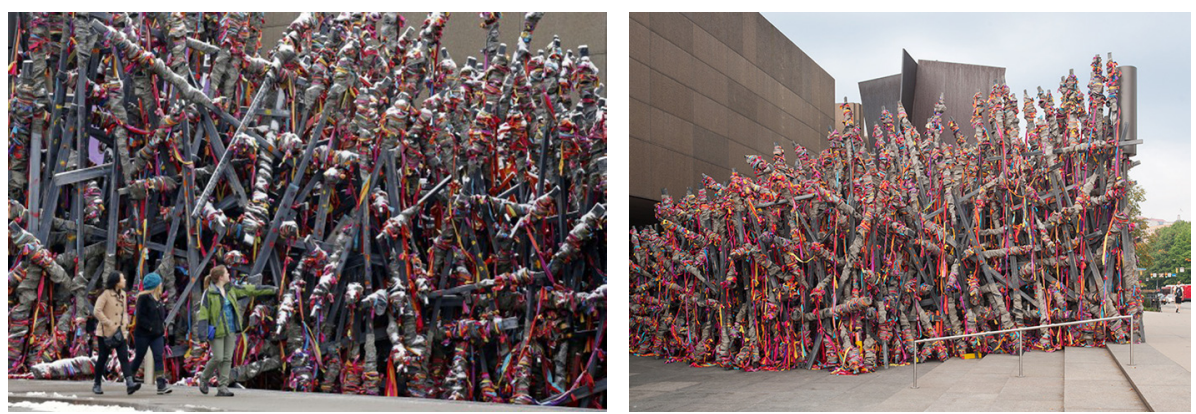

Görsel 9-10. Phllida Barlow, TIP, 2013, Pittsburgh

Phyllida Barlow'un kaba saba malzeme kullanımı ve derme çatma inşa teknikleri çalışmalarının anıtsal boyutuyla çelişmektedir. Sonuçta ortaya çıkan etki anti-anıtsal bir yapı doğurmaktadır. İncelenen tüm örneklerde ortaya çıkan yeni anlam, Polanyi'nin Tacit Boyut yayınının ikinci bölümünde ele aldığı 'oluşma', 'doğma' (emergence) kavramıyla ilişkilenmektedir.

Tacit bilginin iki evresi, detayları içeren yakınsal evre, kapsamlı anlamı içeren uzak evre, ayrı prensiplerle çalışan, gerçekliğin iki seviyesi gibi görülebilir. Üstte olan alttaki elemanların kendi içinde işleyiş̧ kurallarına dayanır, ancak üst işleyiş altta olanın işleyişiyle izah edilemez. Tacit kavrayıs bu iki evrenin birlikte kavrandığı bir eylemdir (Polanyi, 1966: 34). Katmanlar arası hiyerarşinin mantığl; üst katman ancak alt katmanda ortaya konmayan bir sürecin varlık kazanmasıyla oluşma, doğma özelliğini sağlar (Polanyi,1966: 45). Orijinallik yeni değerler doğurduğunda, bunu tacit bir şekilde doğurur, ima yoluyla; açıkça yeni bir dizi değeri seçemeyiz, ama yaratıcı eylem veya sahiplenme yoluyla onları önerebiliriz, sözleriyle henüz tanımlanmamış, söze dökülmemiş, örtük bilginin yapısını ortaya koymaktadır (Polanyi, 1966: xi).

\section{Sonuç}

Görsel sanatlar çok uzun süredir, resmin çerçevesi dışına taşarak yerleştirme, performans, kamusal ve katılımcı sanat gibi alanlarda üretim verirken, izleyicinin sadece bakışını talep etmekten öte, sanatı deneyimlenen bir alana açmak üzere kafa yormaktadır. Yöntemler ve teknolojisi değişse de sanatın kendine özgü bir mantıkta iletişim kurma girişimi varlığını korumaktadır.

Bu konuda Polanyi "Bir resim nedir?" makalesinin sonuç bölümünde, sanatın bizi bu doğal olmayan bilgi alanına taşıma şeklinin, konusu hakkında bilgi vererek değil, onun içinde yaşamamızı sağlayarak gerçekleştirdiğini savunur. Sanatı gerçekleştirirken onu yapan kişinin içinde yaşadığı sürecin paralelinde, yaşamsal bir deneyim aktarılmaktadır. Bu nedenle sanatsal bilginin entelektüel olmaktan öte varoluşsal olduğunu vurgulamaktadır. Sanatın genel olarak ikili uyumsuz yapının birleşiminden oluştuğu fikrini, bir parçanın iletişim kurma girişimi olduğu gibi, diğerinin de bu girişim ile çelişen artistik yapının birleşiminden oluştuğunu dile getirmektedir. Bu yeni bütün doğada ve temel insan ilişkilerinde bulunmayan özellikler doğurmaktadır (Polanyi, 1970: 235).

Sözel olmayan, pratiğin ve malzemenin içeriğiyle aktarılan bilgi türü bugün çağdaş sanatın kavram ve dil ile kurduğu yoğun ilişkinin aksi bir alana bakmakta ve bu bilinçli geri adım araştırmanın temel amacını oluşturmaktadır. Sözel dilin doğrudan egemen olduğu ve dolaşım hızı yüksek iletişim çağında, sanatın gündelik mantığı tersine çevirme biçimi irdelenmektedir. Bu çalışmada, deneyim ve süreci merkeze alan yaklaşımı ile görsel sanatların malzemeyle düşünme pratiğinin, dokunarak bakmanın sağladığı farkındalığın, bu vesileyle bireyin çevreyi algılama ve dönüştürmedeki aktif rolünü sanat yoluyla açığa çıkarma potansiyeli, bir olasılık olarak yeniden ele alınmaktadır.

Sanat pratiğinde, yaparak düşünmenin karşılıklı ilerleyişini gözlemek, belgelemek, anlamlandırmak ve ifade etme gayreti, kullanılan malzeme ve tekniğin ortaya çıkardığı yeni olanak, problem ve soruları üzerine bir içerik geliştirilmekte, sanatın pratik ile şekillenen alanını ve kendine özgü bilgi aktarma biçimini tanımlamamıza olanak sağlamaktadır. 


\section{Kaynakça}

Carter, P. (2004). Material Thinking: The Theory and Practice of Creative Research. Melbourne: Melbourne University Press.

Ingold, T. (20II). Redrawing Anthropology: Materials,Movements, Lines. Surrey : Ashgate Publishing.

Polanyi, M. (1958). Personal Knowledge: Towards a Post-critical Philosophy. New York: Harper Torchbooks.

Polanyi, M. (1966). The Tacit Dimension. New York: Doubleday \& Company Inc.

Polanyi, M. (1970). "What is a Painting?" The British Journal of Aesthetics, 10, 225-236.

Temkin, A. ve Rose, B. (1993). Thinking is Form: The Drawings of Joseph Beuys. London: Thames \& Hudson Publishers.

\section{Görsel Kaynakları}

Görsel I. Web: http://lavieboheme2010.blogspot.com.tr/2013/09/the-tricks-ofsantignazio.html I3.Şubat.20/8'de alınmıştır.

Görsel 2. Web: https://www.artgallery.nsw.gov.au/collection/works/434.1997.9/ 13.Şubat.2018'de alınmıştır.

Görsel 3. Web: http://www.imgrum.org/tag/turkishgrammar 13.Şubat.20I8'de alınmıştır. Görsel 4. Web: http://oyleveyaboyle.blogspot.com.tr/20I I/02/ I3.Şubat.20I8'de alınmıştır.

Görsel 5. Web: http://www.goldsworthy.cc.gla.ac.uk/image/?id=ag_0239/\&t=I 13.Şubat.2018'de alınmıştır.

Görsel 6. Web: https://www.npr.org/20/5//0/08/44673/282/sculptor-turns-rain-iceand-trees-into-ephemeral-works 13.Şubat.2018'de alınmıştır.

Görsel 7. Web: https://hausderkunst.de/en/explore/artists/phyllida-barlow 13 Şubat 2018'de alınmıştır.

Görsel 8. Web: http://www.highhousegallery.com/other-artists/phyllida-barlow/ I 3 Şubat 2018'de alınmıştır.
Görsel 9. Web: https://www.irishexaminer.com/breakingnews/entertainment/sculptorphyllida-barlow-to-represent-britain-at-prestigious-venice-biennale-723734.html (I3. Şubat.2018)

Görsel 10. Web: http://ci /3.cmoa.org/artists/phyllida-barlow I3 Şubat 2018'de alınmıştır. 